Publication is summarization of existing data being results of literature review and our experience on usefulness of selenium as a diagnostic marker selection for control examinations in surveillance and as a marker of patients with high risk of cancers.

Key words: selenium, marker of cancer risk, surveillance.

Contemp Oncol (Pozn) 2015; 19 (1A): A60-A61

DOI: $10.5114 /$ wo.2014.47131

\section{Selenium as a marker of cancer risk and of selection for control examinations in surveillance}

\author{
Marcin Lener ${ }^{1}$, Magdalena Muszyńska ${ }^{1,2}$, Anna Jakubowska ${ }^{1,2}$, \\ Katarzyna Jaworska-Bieniek ${ }^{1}$, Grzegorz Sukiennicki ${ }^{1}$, Katarzyna Kaczmarek ${ }^{1}$, \\ Katarzyna Durda ${ }^{1}$, Tomasz Gromowski ${ }^{1}$, Pablo Serrano-Fernández ${ }^{1}$, \\ Józef Kładny', Anna Wiechowska-Kozłowska ${ }^{4}$, Tomasz Grodzki', \\ Ewa Jaworowska ${ }^{6}$, Jakub Lubiński ${ }^{6}$, Barbara Górecka-Szyld ${ }^{7}$, Grażyna Wilk7, \\ Tomasz Huzarski ${ }^{1}$, Tomasz Byrski ${ }^{1}$, Cezary Cybulski ${ }^{1}$, Jacek Gronwald ${ }^{1}$, \\ Tadeusz Dębniak ${ }^{1}$, Olgierd Ashuryk ${ }^{1}$, Aleksandra Tołoczko-Grabarek ${ }^{1}$, \\ Antoni Morawski ${ }^{2,8}$, Rodney J. Scott ${ }^{9}$, Jan Lubiński ${ }^{1,2}$
}

1Department of Genetics and Pathology, International Hereditary Cancer Centre, Pomeranian Medical University, Szczecin, Poland

${ }^{2}$ Read-Gene SA, Grzepnica, Poland

${ }^{3}$ Department of General and Oncological Surgery, Pomeranian Medical University, Szczecin, Poland

${ }^{4}$ Laboratory of Endoscopy, Division of Heath Care, Ministry of Internal Affairs and Administration in Szczecin, Poland

${ }^{5}$ Specialised Hospital for Lung Diseases, Szczecin-Zdunowo, Poland

${ }^{6}$ Department of Otolaryngology and Laryngological Oncology, Pomeranian Medical University, Szczecin, Poland

'Department of General and Dental Radiology, Pomeranian Medical University, Szczecin, Poland

${ }^{8}$ Institute of Inorganic Chemical Technology and Environmental Engineering, West Pomeranian University of Technology, Szczecin, Poland

${ }^{9}$ Discipline of Medical Genetics, School of Biomedical Sciences, Faculty of Health, University of Newcastle and The Hunter Medical Research Institute, Newcastle, New South Wales, Australia

\title{
Selenium as a marker of selection for control examinations in surveillance
}

There are literature data which clearly demonstrate that identification of low selenium levels can by useful in disease surveillance by such methods as computerised tomography for detection of lung cancers and in colonoscopy for detection of early stage colorectal cancers. More than 20 studies have shown that low serum selenium levels are related to an increased risk of lung cancer. Studies performed by our centre, which evaluated the level of selenium in the serum of 86 patients with lung cancer and 86 healthy controls, have also shown a strong correlation between selenium level and cancer. Among lung cancer cases, the mean selenium level was $63.2 \mathrm{\mu g} / \mathrm{l}$ compared to a mean level of $74.6 \mu \mathrm{g} / \mathrm{l}$ for their matched controls. A 10 -fold reduced risk of lung cancer was also observed in individuals with serum selenium $>80 \mu \mathrm{g} / \mathrm{l}$ as compared to those patients whose serum Se levels were $<60 \mu \mathrm{g} / \mathrm{l}$ [1]. Between 2008-2011 in Szczecin - a single city of four hundred thousand inhabitants in North-West Poland - a programme for early detection of lung cancer was conducted. The enrolment criteria included both sexes, aged 55-65 years, who had a history of at least 20 pack-years of tobacco smoking. The latest addition to the protocol of this programme in 2012 was the inclusion of preselection of participants by measurement of their serum selenium levels. Only individuals with a low selenium level $(<75 \mu \mathrm{g} / \mathrm{l})$ were invited for computerised tomography scans. This new addition to the protocol resulted in more than doubling the detection rate of lung cancers [2]. 
Table 1. The correlation between serum selenium level and the risk of cancers of different sites of origin

\begin{tabular}{|c|c|c|c|c|c|}
\hline Cancer & Quartile & $\begin{array}{l}\text { Selenium level } \\
\qquad(\mu \mathrm{g} / \mathrm{l})\end{array}$ & $\begin{array}{l}\text { No. of cancer/ } \\
\text { controls }\end{array}$ & OR & $p$-value \\
\hline \multirow{4}{*}{$\begin{array}{l}\text { Any except of } \\
\text { breast cancers }\end{array}$} & I & $<65$ & $22 / 16$ & 1 & - \\
\hline & II & $65-79$ & $38 / 87$ & 3.148 & 0.0036 \\
\hline & III & $80-95$ & $28 / 61$ & 2.996 & 0.0094 \\
\hline & IV & $>95$ & $3 / 21$ & 9.625 & 0.0005 \\
\hline
\end{tabular}

There are also about 10 studies that suggest a protective effect of selenium on colorectal adenoma/carcinoma development. In a Polish-Estonian study that evaluated the effect of selenium on the risk of colorectal cancer in 169 cancer cases and 169 healthy controls, a more than 13-fold increased risk of colorectal cancer was found in patients with serum Se levels $<40 \mu \mathrm{g} / \mathrm{l}$ compared to patients whose serum Se levels were $>72 \mu \mathrm{g} / \mathrm{l}$ [3].

Generally, there appears to be little doubt that low selenium level is associated with increased risk of cancer; however, the optimal serum selenium levels can be different for particular populations/countries. For example, in the U.S. the serum level of selenium associated with the lowest risk of colorectal adenomas is $>150 \mu \mathrm{g} / \mathrm{l}$. Such differences between Europe and America can be related to several genetic and environmental factors including exposure to chemical compounds [4].

It is well recognised that for early colorectal cancer detection, colonoscopy is a well-established method for the detection of precancerous conditions and of early cancers. Screening studies using colonoscopy are not widely performed in the world as they are expensive and time consuming. It appears that pre-selection using data based on the levels of serum selenium may be useful in increasing the cost-effectiveness and specificity of detecting precancerous lesions occurring in the colon.

Further investigations are needed to determine the value of serum selenium levels as a selection marker for patient selection for prophylactic screening in other types of tumours, such as cancers of the stomach, pancreas, and prostate.

\section{Selenium and cancer risk}

Data from a meta-analysis of 49 prospective studies revealed that overall the risk of cancer incidence was $31 \%$ lower in the highest category of selenium exposure than in the lowest. Reduction of the number of new cases of cancers with optimised selenium concentration was observed for cancers of the: bladder, lung, larynx, prostate, stomach and colon [5].

In prospective cohort in our Polish centre we found similar correlation for non-breast cancers. In Table 1 we present results on prospectively found 95 cancer (including 19 prostate, 15 colorectal, 14 bladder, 11 lung cancers), matched (by sex, year of birth, cancer family history) $1: 2$ to unaffected individuals with a mean follow-up 19.4 months (range 3-45 months). A few-fold higher risk of cancer can be seen when serum selenium level is under $65 \mu \mathrm{g} / \mathrm{l}$.
In summary, there exists significant evidence that selenium levels may be used as a marker for high cancer risk patient groups and in the selection of persons for appropriate screening and early detection of tumours.

The authors declare no conflict of interest.

\section{References}

1. Jaworska K, Gupta S, Durda K, Muszyńska M, Sukiennicki G, Jaworowska E, Grodzki T, Sulikowski M, Woloszczyk P, Wójcik J, Lubiński J, Cybulski C, Dębniak T, Lener M, Morawski AW, Krzystolik K, Narod SA, Sun P, Lubiński J, Jakubowska A. A low selenium level is associated with lung and laryngeal cancers. PLoS One 2013; 8: e59051.

2. Grodzki T, Wójcik J, Jakubowska A, Wójcik R, Muszyńska M, Kubisa B, Jaworska-Bieniek K, Pieróg J, Gupta S, Alchimowicz J, Gromowski T, Jankowski H, Sukiennicki G, Bielewicz M, Lubiński J. Low selenium serum level is a good preselection factor for patients invited for low dose chest CT lung cancer screening programme. International Association for the Study of Lung Cancer (IASLC). $15^{\text {th }}$ World Conference on Lung Cancer. October 27-31, 2013, Sydney, Australia. Abstract MO11.13.

3. Lener MR, Gupta S, Scott RJ, Tootsi M, Kulp M, Tammesoo ML, Viitak A, Metspalu A, Serrano-Fernández P, Kładny J, JaworskaBieniek K, Durda K, Muszyńska M, Sukiennicki G, Jakubowska A, Lubiński J. Can selenium levels act as a marker of colorectal cancer risk? BMC Cancer 2013; 13: 214.

4. Ou Y, Jiang B, Wang X, Ma W, Guo J. Selenium and colorectal adenomas risk: a meta-analysis. Nutr Cancer 2012; 64: 1153-9.

5. Dennert G, Zwahlen M, Brinkman M, Vinceti M, Zeegers MP, Horneber M. Selenium for preventing cancer. Cochrane Database Syst Rev 2011; (5): CD005195.

\section{Address for correspondence}

\section{Marcin Lener}

Department of Genetics and Pathology International Hereditary Cancer Centre Pomeranian Medical University

Połabska 4

70-115 Szczecin, Poland

phone +48914661532

fax +489146615 33

e-mail: marcinlener@poczta.onet.pl 